\title{
Review
}

\section{The role of laboratory testing in detection and classification of chronic kidney disease: national recommendations}

\author{
Vanja Radišić Biljak*1, Lorena Honović2 , Jasminka Matica ${ }^{3}$, Branka Krešić, Sanela Šimić Vojak \\ On behalf of the joint working group of the Croatian society of medical biochemistry and laboratory medicine and Croatian chamber \\ of medical biochemists for laboratory diagnostics in chronic kidney disease
}

\begin{abstract}
1Department of medical biochemistry and laboratory medicine, Merkur University Hospital, Zagreb, Croatia
${ }^{2}$ Department of medical biochemistry and laboratory medicine, General Hospital Pula, Pula, Croatia

${ }^{3}$ Medical-biochemistry laboratory, Primary care center of the Primorje-Gorski Kotar County, Rijeka, Croatia

${ }^{4}$ Department of medical laboratory diagnostics, University Hospital Centre Split, Split, Croatia

${ }^{5}$ Department of laboratory diagnostics, General County Hospital Požega, Požega, Croatia

*Corresponding author: vanja.radisic@gmail.com
\end{abstract}

\begin{abstract}
Chronic kidney disease (CKD) is a common clinical condition with significant adverse consequences for the patient and it is recognized as a significant public health problem. The role of laboratory medicine in diagnosis and management of CKD is of great importance: the diagnosis and staging are based on estimation of glomerular filtration rate (eGFR) and assessment of albuminuria (or proteinuria). Therefore, the joint working group of the Croatian society of medical biochemistry and laboratory medicine and Croatian chamber of medical biochemists for laboratory diagnostics in CKD issued this national recommendation regarding laboratory diagnostics of CKD.
\end{abstract}

Key factors for laboratories implementing the national guidelines for the diagnosis and management of CKD are:

1. Ensure good communication between laboratory professionals and clinicians, such as nephrologists or specialists in general/family medicine,

2. Ensure all patients are provided with the same availability of laboratory diagnostics,

3. Ensure creatinine assays are traceable to isotope dilution mass spectrometry (IDMS) method and have minimal bias and acceptable imprecision,

4. Select the appropriate GFR estimating formula. Recommended equation is the 2009 Chronic Kidney Disease Epidemiology Collaboration (CKD EPI) equation,

5. In reporting the key laboratory tests (creatinine, eGFR, urine albumin-to-creatinine ratio, urine protein-to-creatinine ratio) use the appropriate reporting units,

6. Provide adequate information on limitations of creatinine measurement.

The manuscript has been organized to identify critical points in laboratory tests used in basic laboratory diagnostics of CKD and is based on the Kidney Disease: Improving Global Outcomes (KDIG0) 2012 Clinical Practice Guideline for the Evaluation and Management of Chronic Kidney Disease.

Key words: chronic kidney disease (CKD); recommendations, estimated glomerular filtration rate (eGFR); albuminuria; proteinuria

\section{Introduction}

Chronic kidney disease (CKD) is a common clinical condition with significant adverse consequences for the patient. It is recognized as a significant public health problem throughout the world (1).
Many publications report the prevalence of CKD in the general population, however there are considerable variation in methods for sampling general population and assessment of kidney function 
across studies (2). This makes comparison of studies rather difficult, however worldwide prevalence of adult CKD is about $10 \%$, reaching up to $50 \%$ in high-risk population (3). Late recognition and diagnosis of disease inevitably leads to kidney failure (1). In this case the only possible therapeutic measure is dialysis or transplantation in health care systems where such treatment is available. In those countries, where access to dialysis and transplantation service may be limited or unavailable, the final consequence of progressive CKD is death. Earlier stages of kidney disease are often asymptomatic and are usually discovered through various comorbid conditions, and may be reversible. It is of great importance, due to right time treatment and improving the quality of life of patients with CKD, but also because of the significant financial savings, to identify disease at an early stage where it is still possible to stop or slow down progression (1). Although, to this point, there had not been official complete epidemiological studies conducted regarding CKD (prof. Mirjana Sabljar Matovinović, personal communication), the availability of treatment in Croatia includes both, dialysis and transplantation (4).

In 2002 the US Kidney Disease Outcomes Quality Initiative (KDOQI) group published the Clinical Practice Guidelines for Chronic Kidney Disease: Evaluation, Classification, and Stratification. Update of these guidelines and recommendations: Clinical Practice Guideline for the Evaluation and Management of Chronic Kidney Disease was released in 2012 under the direction of Kidney Disease: Improving Global Outcomes (KDIGO). Our national recommendations for laboratory diagnosis of chronic kidney disease are mainly based on the $2012 \mathrm{KDIGO}$ guidelines, and written permission was obtained to reproduce the parts of the KDIGO guidelines. KDIGO guidelines are the product of cooperation of a large number of international experts who created recommendations, among other things, to be used for good laboratory practice in the diagnosis and management of CKD.

Chronic kidney disease is defined as an abnormality of kidney structure or function with implications on the health of an individual, and it is present for more than three months. Chronic kidney
TABLE 1. Criteria for chronic kidney disease (CKD) diagnosis*

\begin{tabular}{ll}
\hline $\begin{array}{l}\text { Markers } \\
\text { of kidney } \\
\text { damage }\end{array}$ & $\begin{array}{l}\text { 1. Albuminuria (AER } \geq 30 \mathrm{mg} / 24 \text { hours; ACR } \\
\text { (one or more) }\end{array}$ \\
& $\begin{array}{l}\text { 2. Urine sediment abnormalities } \\
\text { 3. Electrolyte and other abnormalities due } \\
\text { to tubular disorders }\end{array}$ \\
& $\begin{array}{l}\text { 4. Abnormalities detected by histology } \\
\text { 5. Structural abnormalities detected by } \\
\text { imaging }\end{array}$ \\
& 6. History of kidney transplantation \\
\hline $\begin{array}{l}\text { Decreased } \\
\text { GFR }\end{array}$ & GFR $<60 \mathrm{~mL} / \mathrm{min} / 1.73 \mathrm{~m}^{2}$ (GFR categories \\
\hline
\end{tabular}

*Either of the following should be present for $>3$ months. AER - albumin excretion rate. ACR - albumin-to-creatinine ratio. GFR - glomerular filtration rate.

(Reproduced with permission from KDIGO 2012 Clinical Practice Guideline for the Evaluation and Management of Chronic Kidney Disease. Kidney Int, Suppl 2013;3:1-150.)

disease is a general term for heterogeneous disorders affecting kidney structure and function with variable clinical presentation (1). Rational approach to the diagnosis and evaluation of CKD involves simultaneous assessment and monitoring of renal function (through estimated glomerular filtration rate (eGFR), serum creatinine) and kidney damage (albuminuria and/or proteinuria) (Table 1).

One of the prominent criteria for the diagnosis of CKD is decreased GFR value $\left(<60 \mathrm{~mL} / \mathrm{min} / 1.73 \mathrm{~m}^{2}\right)$. GFR is widely accepted as the best index of kidney function. The normal value in young adult men and woman is approximately $125 \mathrm{~mL} / \mathrm{min} / 1.73 \mathrm{~m}^{2}$. Values below $15 \mathrm{~mL} / \mathrm{min} / 1.73 \mathrm{~m}^{2}$ indicate kidney failure and the person can be identified as a candidate for dialysis or renal replacement therapy/kidney transplantation (1). The role of laboratory medicine in diagnosis and management of CKD is of great importance because a very simple test can identify people who are at risk of developing CKD. All that is required is measuring the concentration of serum creatinine and reporting of eGFR, using the available predictive equations.

For an initial assessment of proteinuria the following measurements are recommended (in descending order of preference):

1. urine albumin-to-creatinine ratio $(A C R)$, or

2. urine protein-to-creatinine ratio $(P C R)$. 
In all cases an early morning urine sample is preferred, but does not exclude spot urine samples. Measuring the concentration of urine albumin is preferred to measuring the concentration of urine total protein. Use of urine albumin measurement as the preferred test for proteinuria detection will improve the sensitivity, quality, and consistency of the approach to early detection and management of kidney disease. Albumin (or total protein) concentration in the urine sample should be reported in proportion to the concentration of creatinine (ACR or PCR) in the same sample to minimize the influence of the patient's hydration and the concentration of the urine sample. The reporting of the results is the same for both first morning and spot urine samples, respectively. A positive finding of albuminuria in a random sample of urine needs to be confirmed in the next morning void urine. If a more accurate assessment of albuminuria (or total proteinuria) is required, it is recommended to measure albumin excretion rate (AER) or total protein excretion rate in a timed urine sample $(1,5,6)$. The choice of a suitable timed sample type should be of a laboratory manager. Adequate sample type, time of collection and instructions for patients should be provided by institution.

Some of the other laboratory criteria for diagnosing CKD include urine sediment abnormalities as markers of kidney damage (Table 1). This may include some formed elements, such as renal tubular cells, red blood cells (RBC) casts, white blood cell (WBC) casts, coarse granular casts, wide casts and large numbers of dysmorphic RBCs. Abnormalities of electrolytes (Table 1) may result from disorders of renal tubular reabsorption and secretion. These syndromes are uncommon but pathognomonic of kidney disease (1).

Grading of CKD is based almost exclusively on two laboratory parameters: eGFR (GFR categories 1 to 5 (G1 - G5)) and albuminuria (albuminuria categories 1 to $3(A 1-A 3)$ ) (Table 2). It is also used for the prognosis of progression of the disease (1).

Depending on the category, patients are classified as low-risk patients, highlighted in green, moderate risk (yellow), high risk (orange) and very high risk patients (highlighted in red).

CKD testing using eGFR and ACR should be offered to people with any of the following risk factors:

- diabetes

- hypertension

- acute kidney injury

- cardiovascular disease (ischaemic heart disease, chronic heart failure, peripheral vascular disease or cerebral vascular disease)

TABLE 2. Prognosis of CKD by eGFR categories and albuminuria: KDIGO 2012

\begin{tabular}{|c|c|c|c|c|c|c|}
\hline & & & & \multicolumn{3}{|c|}{$\begin{array}{l}\text { Persistent categories of albuminuria } \\
\text { Description and range }\end{array}$} \\
\hline & & & & $\mathrm{A} 1$ & $\mathrm{~A} 2$ & A3 \\
\hline & & & & $\begin{array}{l}\text { Normal to } \\
\text { mildly increased }\end{array}$ & $\begin{array}{l}\text { Moderately } \\
\text { increased }\end{array}$ & $\begin{array}{l}\text { Severely } \\
\text { increased }\end{array}$ \\
\hline & & & & $<3 \mathrm{mg} / \mathrm{mmol}$ & $\begin{array}{c}3-30 \mathrm{mg} / \\
\mathrm{mmol}\end{array}$ & $>30 \mathrm{mg} / \mathrm{mmol}$ \\
\hline & G1 & Normal or high & $\geq 90$ & & & \\
\hline 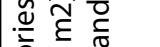 & $\mathrm{G} 2$ & Mildly decreased & $60-89$ & & & \\
\hline 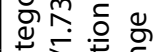 & G3a & Mildly to moderately decreased & $45-59$ & & & \\
\hline 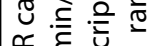 & $\mathrm{G} 3 \mathrm{~b}$ & Moderately to severely decreased & $30-44$ & & & \\
\hline 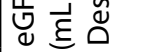 & G4 & Severely decreased & $15-29$ & & & \\
\hline & G5 & Kidney failure & $<15$ & & & \\
\hline
\end{tabular}

Green represents low risk (if no other markers of kidney disease, no CKD). Yellow represents moderately increased risk. Orange represents high risk. Red represents very high risk.

(Reproduced with permission from KDIGO 2012 Clinical Practice Guideline for the Evaluation and Management of Chronic Kidney Disease. Kidney Int, Suppl 2013;3:1-150.) 
- structural renal tract disease, recurrent renal calculi or prostatic hypertrophy

- multisystem diseases with potential kidney involvement - for example, systemic lupus erythematosus

- family history of end-stage kidney disease (GFR category G5) or hereditary kidney disease

- opportunistic detection of haematuria (7).

\section{Background}

Recently, it was shown that laboratory diagnostics of chronic kidney disease in Croatia is not standardized (8). There is a large heterogeneity among Croatian medical biochemistry laboratories regarding creatinine methods and used reference intervals and types of preferred samples for urine albumin (or protein). The most important issue that occured is the fact that laboratories still use non-standardized methods for creatinine results and do not report eGFR values. Also, the majority of laboratories do not measure urine albumin, especially in primary care health setting (8). These facts set the background for the process of standardization and harmonization in this area of laboratory medicine. These national guidelines, based on the relevant 2012 KDIGO Guideline (1), represent the first step in accomplishing this goal.

Key factors for laboratories implementing the national guidelines for the diagnosis and management of CKD are:

1. Ensure good communication between laboratory professionals and relevant clinicians, such as nephrologists or specialists in general/family medicine,

2. Ensure all patients are provided with the same availability of laboratory diagnostics,

3. Ensure creatinine assays are traceable to isotope dilution mass spectrometry (IDMS) method and have minimal bias and acceptable imprecision,

4. Select the appropriate GFR estimating formula. Recommended equation is the 2009 Chronic Kidney Disease Epidemiology Collaboration (CKD - EPI) equation,

5. In reporting the key laboratory tests (creatinine, eGFR, urine albumin-to-creatinine ratio (ACR), urine protein-to-creatinine ratio (PCR)) use the appropriate reporting units,

6. Provide adequate information on limitations to creatinine measurement (9).

\section{Recommedations}

The national recommendations are mainly based on the KDIGO 2012 guidelines, however, novel literature findings are also incorporated. Our main goal was to provide recommendations that can be easily applied in every medical biochemistry laboratory in Croatia. The draft of the recommendations was sent to numerous national and international experts for their comments. The manuscript was also made available for public consultation. All comments were carefully considered and incorporated into the final version of the recommendations.

The document consists of four main parts with corresponding subheadings:

1. Creatinine

1.1. Preanalytical phase

1.2. Analytical phase

1.3. Postanalytical phase

1.4. Pediatric considerations

2. eGFR

\subsection{Equations}

2.2. Preanalytical phase

2.3. Postanalytical phase

2.4. Pediatric considerations

3. ACR

3.1. Preanalytical phase

3.2. Analytical phase

3.3. Postanalytical phase

3.4. Pediatric considerations

4. $P C R$

4.1. Preanalytical phase

4.2. Analytical phase

4.3. Postanalytical phase

4.4. Pediatric considerations.

The manuscript is organized to identify critical points in four major laboratory tests used in basic 
laboratory diagnostics of CKD. It is rather difficult to give unique and uniform recommendations, regarding a large heterogeneity amongst methods and populations. Our intention was to point out to some weak points in pre- and analytical phase, but every laboratory must set their own specifications for method performance and handling the specimens, according to their possibilities and conditions.

An easy-to-follow step-by-step approach in implementation of the recommendations is shown in Appendix 1.

To ensure the better flow of information in implementing national guidelines laboratories can use the provided template (Appendix 2) (10).

\section{Creatinine}

An important limiting factor in the use of predictive equations for GFR estimation is an accurate method for determining serum creatinine concentration.

\subsection{Preanalytical phase}

There are numerous well known preanalytical variations that affect serum creatinine concentration which are listed in the Table 3.

The majority of listed variations are non-controllable, however both laboratory professionals and clinicians should be aware of those limitations. The laboratory professionals are referred to previously

TABLE 3. Sources of errors in GFR estimation using creatinine

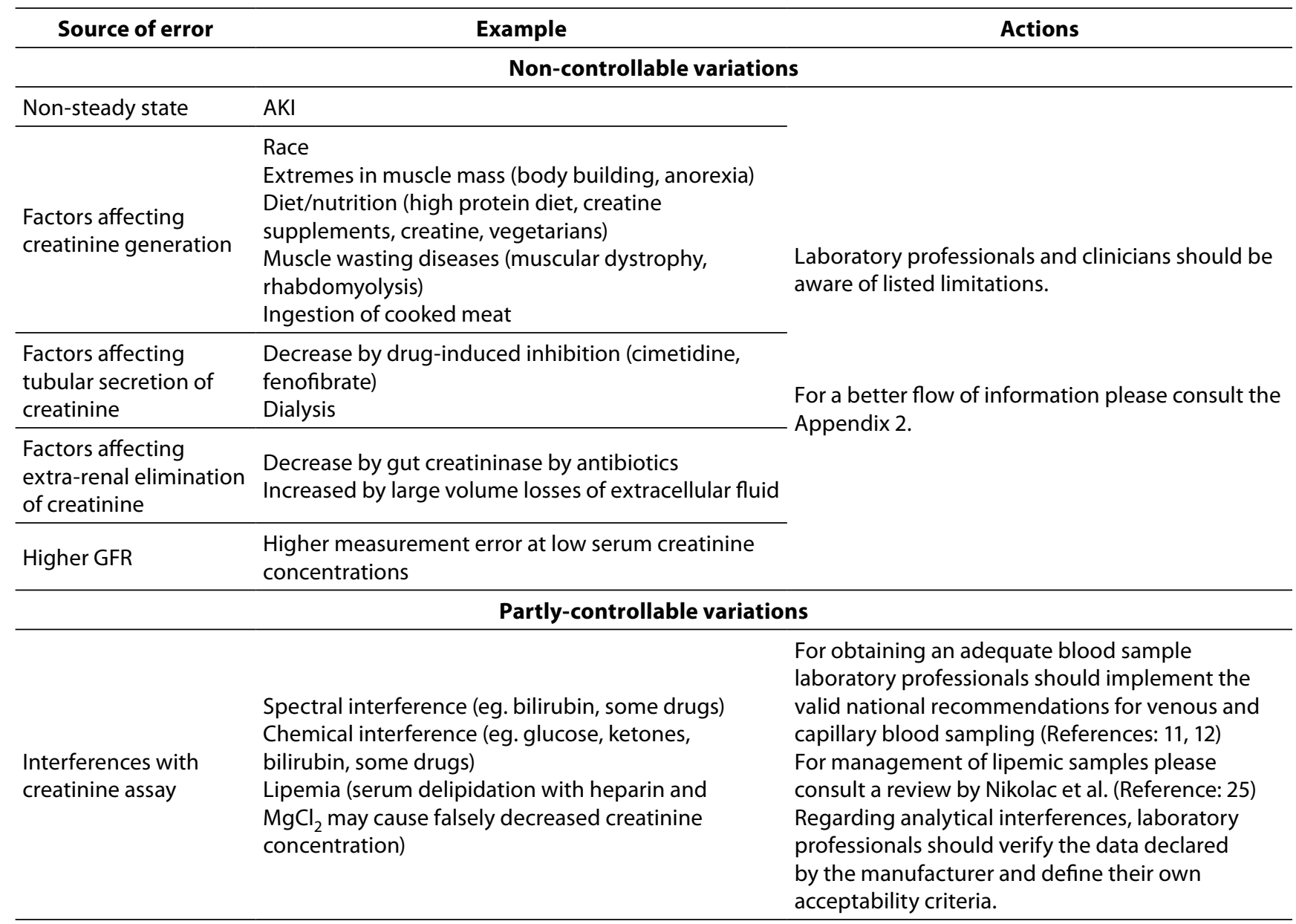

AKI - acute kidney injury. GFR - glomerular filtration rate.

(Reproduced with permission from KDIGO 2012 Clinical Practice Guideline for the Evaluation and Management of Chronic Kidney

Disease. Kidney Int, Suppl 2013;3:1-150.) 
mentioned Appendix 2 which will be of assistance in communication with patients, as well as with the ordering physicians. For a minor part of variations that can be controlled regarding sample quality, laboratory professionals are referred to the published national recommendations for venous and capillary blood sampling $(11,12)$.

\section{Stability}

Creatinine, in a non-separated serum sample, which is in contact with a blood clot, is stable for 24 hours. In a separate serum sample creatinine is stable for 7 days at room temperature $\left(20-25^{\circ} \mathrm{C}\right)$, or stored in a refrigerator $\left(2-8^{\circ} \mathrm{C}\right)$. Serum samples stored at $-20^{\circ} \mathrm{C}$ are stable for 3 months with 10 freeze-thaw cycles (13).

\subsection{Analytical phase}

To universally implement eGFR based on serum creatinine measurements, standardization of routine serum creatinine measurements is required. For the measurement of serum creatinine, laboratories should use the recommended method with calibration traceable to international standard reference material and minimal bias compared to the IDMS method (1).

Desirable and optimal specification for imprecision, bias and total error according to biological variation database $(14,15)$ are shown in Table 4.

Recommended methods for serum creatinine measurements in Croatia are: photometric compensated Jaffé method traceable to IDMS method and enzymatic method traceable to IDMS method and The National Institute of Standards and Technology Standard Reference Material (NIST SRM) 967 for creatinine in serum (16). However, there is emerging evidence that enzymatic creatinine assays lead to less variability in measurements of serum creatinine and are preferably used in clinical practice in order to generate more reliable GFR estimates (17-19).

Standardization (compensation) of photometric Jaffé method involves changing the values of calibrators in terms of traceability to the IDMS method and change of corresponding intercept (or factor $B$, depending on the analyzer). Considering the fact that there are many creatinine assays available that may not be IDMS traceable, and that for assays which may be IDMS traceable, the information supplied does not make this clear to the user (20), for new values of calibrators, controls and intercept, laboratory professionals should contact the person in charge of applications from companies providing reagents, controls and calibrators or whose analyzer is on which creatinine is measured. The list of available creatinine assays, as well as traceability information, is given in the Appendix 3 . However, laboratory professionals should be aware that this list is susceptible to changes and they should always be correctly informed by the latest Information for use (IFU) leaflet.

Standardization of calibration does not correct for analytical interferences. The enzymatic assays may be less influenced by non-creatinine chromogens

TABLE 4. Specifications for imprecision, inaccuracy and allowable total error

\begin{tabular}{lcccccc}
\hline & \multicolumn{2}{c}{ Desirable specification } & \multicolumn{2}{c}{ Optimal specification } \\
\cline { 2 - 7 } & I (\%) & B (\%) & TE (\%) & I (\%) & B (\%) & TE (\%) \\
\hline Serum creatinine & 3.0 & 4.0 & 8.9 & 2.8 & 3.2 & 7.7 \\
\hline Creatinine, concentration, first morning urine & 11.6 & 8.7 & 27.8 & NA & NA & NA \\
\hline Total protein, 24 hour urine & 17.8 & 10.7 & 40.0 & 8.9 & 5.3 & 20.0 \\
\hline Albumin, concentration, first morning urine & 18.0 & 16.4 & 46.1 & 9.9 & 7.0 & 23.3 \\
\hline
\end{tabular}

I - specification for imprecision. B - specification for inaccuracy. TE - specification for allowable total error. NA - not applicable. 
compared to the Jaffé assays $(21,22)$, but no procedure was unaffected. The most common analytical interferences are caused by endogenous substances: high bilirubin concentration, glucose, proteins, pyruvate, $\beta$-hydroxybutyric acid, low albumin, as well as many drugs (cephalosporins, dobutamine, lidocaine) (23). High bilirubin concentrations may interfere with the Jaffé method, where the assay absorbance is near the bilirubin absorbance peak of $\sim 456 \mathrm{~nm}$. Jaffé reaction may also be affected by lipemia and/or haemolysis. Haemolysed samples that contain fetal haemoglobin (HbF) interfere with the Jaffé reaction, and it is possible to obtain negative creatinine results (24). Management of lipemic samples was extensively explained in the review by Nikolac et al. (25).

The influence of interfering substances is greater at creatinine concentrations within reference range than at higher concentrations. Magnitude and direction of bias in creatinine concentration depends on the details of implementation of the method principle (26). The influence of interfering substances is less frequent with the enzymatic procedures, however no procedure is unaffected and is method and analyzer dependent $(21,27)$. Interference (endogenous or exogenous) if unrecognized lead to false laboratory result and consequently to incorrect diagnosis. To systematize corrective actions, as a part of the total quality system, when interference appears first step must be manufacturer's method specification in which are listed interference studies conducted by the manufacturer (28). However, it was shown that there are serious discrepancies between manufacturer's declarations and measured data (29). Each laboratory should verify the data declared by the manufacturer and define its own acceptability criteria (30).

Because urine contains relatively little or no protein, both enzymatic and Jaffé method are suitable for urine creatinine measurement (1).

\subsection{Postanalytical phase}

When reporting serum and urine creatinine concentrations obtained by a standardized assay, laboratories should use revised reference intervals published by Croatian chamber of medical biochemists (CCMB) in 2010 (31,32) which are shown in Table 5.

The applicability of the recommended "common" reference intervals in all Croatian laboratories measuring serum creatinine concentrations were confirmed in the study conducted by FlegarMeštrić et al. (33). This fulfils the prerequisite for implementation of international guidelines for early diagnosis and prediction of progression of chronic kidney disease using glomerular filtration rate CKD-EPI estimating equation $(34,35)$.

\subsection{Pediatric considerations}

Children show lower reference ranges for total protein, thus the protein error in Jaffé method is considerably smaller, which, in consequence, with restandardized Jaffé-type assays, could lead to negative values in children with a decreased muscle mass (36). Therefore, the only recommended method for the measurement of serum creatinine in pediatric patients (individuals younger than 18 years) is enzymatic assay (37).

The persisting problem of pediatric reference intervals has been substantially reduced with the establishment of a new comprehensive database of pediatric reference intervals as a part of the Canadian Laboratory Initiative in Pediatric Reference Intervals (CALIPER) study $(38,39)$. It should assist laboratorians and pediatricians in interpreting test results more accurately. There are already some transference studies with other analytical platforms and local populations, as recommended by the CLSI $(40,41)$. Laboratory professionals should also be aware of the International Federation for Clinical Chemistry and Laboratory Medicine (IFCC) Pediatric Reference Range Initiatives with many useful information on this delicate topic (42). 
TABLE 5. Revised recommended methods and reference intervals for serum and urine creatinine measurement

\begin{tabular}{|c|c|c|c|c|}
\hline \multirow{2}{*}{ Analyte } & \multirow{2}{*}{ SI Units } & \multicolumn{3}{|c|}{ Reference intervals } \\
\hline & & Gender & Age & Interval \\
\hline \multirow{12}{*}{ Serum creatinine } & \multirow{12}{*}{$\mu \mathrm{mol} / \mathrm{L}$} & & Prenatal (umbilical cord) & $46-86$ \\
\hline & & newborn babies & $0-14$ days & $27-81$ \\
\hline & & male, female & 2 months $\leq 1$ year & $14-34$ \\
\hline & & male, female & $1 y \leq 3 y$ & $15-31$ \\
\hline & & male, female & $3 y \leq 5 y$ & $23-37$ \\
\hline & & male, female & $5 y \leq 7 y$ & $25-42$ \\
\hline & & male, female & $7 y \leq 9 y$ & $30-48$ \\
\hline & & male, female & $9 y \leq 11 y$ & $28-57$ \\
\hline & & male, female & $11 \mathrm{y} \leq 13 \mathrm{y}$ & $37-63$ \\
\hline & & male, female & $13 y \leq 15 y$ & $40-72$ \\
\hline & & male & adults (18 - 74 y) & $64-104$ \\
\hline & & female & adults $(18-74 \mathrm{y})$ & $49-90$ \\
\hline \multirow{5}{*}{$\begin{array}{l}\text { Urine creatinine } \\
\text { ( } 24 \text { hour urine sample) }\end{array}$} & \multirow{5}{*}{$\mathrm{mmol} / 24$ hour } & male, female & $3-8 y$ & $1.0-6.0$ \\
\hline & & male, female & $9-12 y$ & $1.5-12.5$ \\
\hline & & male, female & $13-17 y$ & 2.6. -16.5 \\
\hline & & male & adults & $7.7-21.3$ \\
\hline & & female & adults & $5.9-14.1$ \\
\hline \multirow{2}{*}{$\begin{array}{l}\text { Urine creatinine } \\
\text { (first morning sample) }\end{array}$} & \multirow{2}{*}{$\mathrm{mmol} / \mathrm{L}$} & male & adults & $3.5-22.9$ \\
\hline & & female & adults & $2.5-19.2$ \\
\hline
\end{tabular}

y - years. (Reproduced and adapted with the permission of Croatian Chamber of Medical biochemists, document in Croatian. Available at: http://www.hkmb.hr/obavijesti/arhiva2010/arhiva_2010.html.)

\section{Recommendations}

1. Methods for serum creatinine measurement should be traceable to IDMS method and NIST SRM 967.

2. For urine creatinine measurement both enzymatic and Jaffé method are suitable.

3. When reporting serum and urine creatinine values obtained by a standardized assay, laboratories should use revised reference intervals published by CCMB.

4. The recommended method for serum creatinine measurement in pediatric patients ( $<18$ years) is the enzymatic assay.

5. For pediatric reference intervals consult CALIPER database (http://www.sickkids.ca/Caliperproject/ intervals/index.html ) and other available literature data, such as IFCC Pediatric Reference Range Initiatives (http://www.ifcc.org/task-force-paediatric-laboratory-medicine-web-pages/paediatric-reference-range-initiatives/). 


\section{2. eGFR}

\subsection{Equations}

The recommended equation for GFR estimation in adult population ( $\geq 18$ years) is CKD-EPI equation $(1,43,44)$. The equation includes four variables: serum creatinine concentration, age, sex and race (Table 6) (34). Although all equations for GFR estimation are essentially mathematical abstractions that relate patients to the populations from which the equations were derived (45), there is growing body of evidence that CKD-EPI equation is superior in general population $(5,46)$, as well as in diabetic patients (47-49).

In situations where GFR estimating equations are limited including extremes of body size and age, conditions after limb amputation, pregnancy, severe malnutrition or obesity, muscle wasting diseases, paraplegia and quadriplegia, vegetarian diet, rapidly changing kidney function, when determining eligibility for kidney donation or adjusting dosage of toxic drugs that are excreted by the kidneys and in research projects in which estimating glomerular filtration rate is a primary goal, GFR should be measured using standardized creatinine clearance measurement $(1,50)$.

\subsection{Preanalytical phase}

eGFR may be falsely decreased after a meal of high meat content, as blood creatinine concentration increases after meal intake (51).
Blood creatinine is predominantly derived from muscle, eg. a muscular young man may have increased serum creatinine concentration and a falsely lowered eGFR. eGFR increases by $2.3 \mathrm{~mL} /$ $\mathrm{min} / \mathrm{kg}$ of lean mass in healthy men (52).

Low eGFR finding should be confirmed with a repeated sample taken after avoidance of meat for at least 12 hours. Spurious causes of low eGFR, such as high muscle mass, should be considered. Additionally, a low eGFR should prompt a check for proteinuria assessment (51).

\subsection{Postanalytical phase}

Diagnosis, prognosis prediction and progression of CKD using eGFR is not based on comparing the values to population based reference intervals but on diagnostic values defined as categories in classification system shown in Table 2 . Implementation of equations listed in Table 6, in laboratory information system is necessary for calculating eGFR using CKD-EPI equation. Recommended equations relate to white race. For calculating eGFR in black race, obtained result must be multiplied by 1.159. When reporting eGFR results, they should be rounded to a nearest whole number using the recommended units $\mathrm{mL} / \mathrm{min} / 1.73 \mathrm{~m}^{2}$. eGFR values should be reported with requests for serum creatinine concentration in adults (5).

Glomerular filtration rate physiologically decreases with ageing by approximately $1 \mathrm{~mL} / \mathrm{min} /$ year of age $(52,53)$. Although an eGFR values $<60 \mathrm{~mL} /$

TABLE 6. Recommended equations for GFR estimation

\begin{tabular}{|c|c|c|}
\hline \multicolumn{3}{|c|}{2009 CKD-EPI EQUATION (adults $\geq 18$ years) } \\
\hline Gender & Serum creatinine ( $\mu \mathrm{mol} / \mathrm{L})$ & Equation (for patients $\geq 18$ years) \\
\hline Female & $\leq 62$ & eGFR $=144 \times(\text { creat } / 62)^{-0.329} \times(0.993)^{\text {age }}$ \\
\hline Female & $>62$ & eGFR $=144 \times(\text { creat } / 62)^{-1.209} \times(0.993)$ age \\
\hline Male & $\leq 80$ & eGFR $=141 \times(\text { creat } / 80)^{-0.411} \times(0.993)$ age \\
\hline Male & $>80$ & eGFR $=141 \times(\text { creat } / 80)^{-1.209} \times(0.993)$ age \\
\hline \multicolumn{3}{|c|}{ For black race use a multiplier of 1.159} \\
\hline \multicolumn{3}{|c|}{ SCHWARTZ EQUATION (children < 18 years) } \\
\hline
\end{tabular}

GFR $\left(\mathrm{mL} / \mathrm{min} / 1.73 \mathrm{~m}^{2}\right)=(36.2 \times$ height $) /$ creatinine

(height in $\mathrm{cm}$, serum creatinine in $\mu \mathrm{mol} / \mathrm{L}$ ) 
$\mathrm{min} / 1.73 \mathrm{~m}^{2}$ are very common in older people (5), it is predictive for increased risk of adverse clinical outcomes and age related diagnostic values for eGFR are not recommended in adults.

Based on the biological and analytical variation of serum creatinine, the reference change value (RCV) for eGFR is about $14 \%$.

\subsection{Pediatric considerations}

For estimation of GFR in pediatric population we recommend Schwartz equation with obligatory use of enzymatic assay for the measurement of serum creatinine concentration $(54,55)$. The equation is applicable for children from 1 to 18 years old.
Routine calculation of eGFR is not recommended in children and youth (5). Every eGFR result calculated by Schwartz equation above than $75 \mathrm{~mL} /$ $\mathrm{min} / 1.73 \mathrm{~m}^{2}$ should not be reported as a whole number but as "> $75 \mathrm{~mL} / \mathrm{min} / 1.73 \mathrm{~m}^{24}$.

In children younger than 2 years of age with CKD, the GFR categories as per the adult in Table 2 do not apply; these children should be categorized as having normal, moderately reduced, or severely reduced age-adjusted GFR. No currently agreed upon set of international normative values or categories exist for GFR in children under the age of 1-2 years. However, the international pediatric nephrology community has embraced the adult CKD staging system as per the $2002 \mathrm{KDOQ}$ I guidelines in children over the age of 2 years (1).

\section{Recommendations}

1. Laboratories should implement the 2009 CKD-EPI equation for estimation of GFR.

2. eGFR results should be reported with serum creatinine results in adults.

3. eGFR results should be rounded to a nearest whole number using the recommended units $\mathrm{mL} /$ $\mathrm{min} / 1.73 \mathrm{~m}^{2}$.

4. Age related diagnostic values for eGFR are not recommended in adults.

5. Low eGFR values should be confirmed with a repeat sample taken after avoidance of meat at least 12 hours. Additionally, spurious causes of low eGFR should be considered and should prompt a check for proteinuria.

6. RCV for eGFR is $~ 14 \%$.

7. The recommended equation for children under 18 years is the Schwartz equation.

8. Routine calculation of eGFR is not recommended in children and youth.

9. Every eGFR result calculated by Schwartz equation above than $75 \mathrm{~mL} / \mathrm{min} / 1.73 \mathrm{~m}^{2}$ should be reported as "> $75 \mathrm{~mL} / \mathrm{min} / 1.73 \mathrm{~m}^{2 "}$.

10. The GFR categories (listed in the Table 2) do not apply in children under 2 years of age.

\section{ACR}

\subsection{Preanalytical phase}

Albumin intra- and inter-individual biological variation are important factors for selecting appropriate urine sample, for the interpretation of the confirmation results and for assessing clinically signifi- cant difference in albumin concentration. ACR in the first morning urine has a significantly lower intra-individual variation, compared to the albumin concentration in 24-hour urine. This represents an important fact considering the pitfalls in collecting 24-hour urine samples (56). Table 7 presents the factors affecting urinary ACR $(1,57)$. 
The majority of the variations listed are non-controllable, however both laboratory professionals and clinicians should be aware of those limitations. Controllable variations include obtaining an adequate urine sample. The patient should be adequately prepared and told why a urine specimen requires to be examined. Instructions on how it should be collected should be given, ideally both orally and in written form, following the national recommendations issued by CCMB about standards of good laboratory practice in obtaining adequate urine samples (58). Biological (in vivo) factors, changing the true concentration of a measured component, cause problems in the interpretation of laboratory results, although the measurement process itself is correct. They are called influence factors and patients should be adequately explained about possible interferences (59).

\section{Stability}

Albumin is stable in urine samples without preservatives at least one week when stored at $2-8^{\circ} \mathrm{C}$. For an extended period it is recommended to freeze the sample at $-80^{\circ} \mathrm{C}$, without centrifugation or filtration. After sample thawing, possible precipitates can be easily removed by dissolving the sample at $37^{\circ} \mathrm{C}$. Blurry urine samples should be centrifuged (60).

\subsection{Analytical phase}

Recommended methods for the measurement of urine albumin are immunochemistry assays, specific and precise at low albumin concentrations, that produce quantitative results in clinically relevant range. Albumin is mainly measured using turbidimetric assays. Currently there is no reference measurement procedure or standardized reference material recommended by the Joint Committee on Traceability in Laboratory Medicine (JCTLM). At the moment the LC-IDMS method developed at the Mayo Clinic Renal Reference Laboratory is under validation at the National Institute for Standards and technology (NIST) before being submitted to the JCTLM for listing (61). Most methods are standardized against the Standard Reference Material 470 (SRM 470) distributed by the Institute for Reference Materials and Measurements (IRMM) of the European Commission (1), however the NIST SRM 2925 containing pure albumin intended for calibration of LC-IDMS is now available. The commutability assessment of the NIST SRM 3666 containing albumin in frozen human urine intended for calibration of routine measurements procedures is at the moment under investigation (61). Since the results are expressed in proportion to the concentration of creatinine, urine creatinine should be measured in the same urine sample.

Desirable and optimal specifications for imprecision, bias and total error according to biological variation database (14) are shown in Table 4.

Samples with very high albumin concentration may give falsely low or normal results due to the prozone effect. In this case it is necessary to repeat the analysis after dilution of the sample.

The main causes of variation in urine albumin measurement are outside the analytical process, in preanalytical (as described in the previous subheading) and postanalytical phases (different units, different cut-off values, different ways of reporting the results). Other causes of variation are different forms of albumin in urine, which are significantly different from each other even between healthy individuals. Urine albumin is exposed to modifying factors such as wide range of $\mathrm{pH}$ and ionic strength, high concentrations of urea, glucose and ascorbate, and cleavage by peptidases (62).

\subsection{Postanalytical phase}

The presence of albumin in urine should be expressed as categories of classification system shown in Table 2. The term microalbuminuria is no longer recommended.

The results should be reported as ACR expressed as $\mathrm{mg} / \mathrm{mmol}$. If the presence of albumin in urine is measured as AER results should be reported using the units $\mathrm{mg} / 24$ hours with reference interval $<30$ $\mathrm{mg} / 24$ hours, independently of sex and age.

\subsection{Pediatric considerations}

There is no set standard encompassing all children with respect to the normal range of urinary protein (or albumin) excretion. Values vary across age, sex, 
TABLE 7. Factors affecting urinary $A C R$ and $P C R$

\begin{tabular}{|c|c|c|}
\hline Factor & Examples of effect & Actions \\
\hline \multicolumn{3}{|c|}{ Non-controllable variations } \\
\hline $\begin{array}{l}\text { Intraindividual } \\
\text { variability }\end{array}$ & Genetic variability & \\
\hline $\begin{array}{l}\text { Non-renal causes } \\
\text { of variability in } \\
\text { creatinine excretion }\end{array}$ & $\begin{array}{l}\text { Age (lower in children and elderly) } \\
\text { Race (lower in Caucasians than black people) } \\
\text { Muscle mass (lower in people with amputations, } \\
\text { paraplegia, muscular dystrophy) } \\
\text { Gender (lower in women) }\end{array}$ & $\begin{array}{l}\text { Laboratory professionals and clinicians should be aware } \\
\text { of listed limitations. }\end{array}$ \\
\hline $\begin{array}{l}\text { Changes in } \\
\text { creatinine excretion }\end{array}$ & AKI & $\begin{array}{l}\text { For a better flow of information please consult the } \\
\text { Appendix } 2 \text {. }\end{array}$ \\
\hline \multicolumn{3}{|c|}{ Partly-controllable variations } \\
\hline $\begin{array}{l}\text { Transient elevation } \\
\text { in albuminuria }\end{array}$ & $\begin{array}{l}\text { Menstrual blood contamination } \\
\text { Symptomatic urinary tract infections } \\
\text { Exercise } \\
\text { Orthostatic proteinuria } \\
\text { Other conditions increasing vascular permeability } \\
\text { (eg. septicemia, significant hypertension, fever) }\end{array}$ & $\begin{array}{l}\text { For obtaining an adequate sample laboratory } \\
\text { professionals should implement standards of good } \\
\text { laboratory practice issued by CCMB, available at: http:// } \\
\text { www.hkmb.hr/povjerenstva/strucna-pitanja.html }\end{array}$ \\
\hline $\begin{array}{l}\text { Transient elevation } \\
\text { in proteinuria }\end{array}$ & $\begin{array}{l}\text { Vaginal and urethral secretions contamination } \\
\text { Exercise } \\
\text { Dehydration } \\
\text { Very high protein intake } \\
\text { Emotional stress } \\
\text { Diluted urine specimens can give false negative } \\
\text { protein results }\end{array}$ & $\begin{array}{l}\text { Patients should be thoroughly explained about possible } \\
\text { in vivo influence factors. }\end{array}$ \\
\hline \multicolumn{3}{|c|}{ Controllable variations } \\
\hline \multirow{2}{*}{$\begin{array}{l}\text { Preanalytical } \\
\text { storage conditions }\end{array}$} & Degradation of albumin before analysis & $\begin{array}{l}\text { Albumin is stable in urine samples without preservatives at } \\
\text { least one week when stored at } 2-8^{\circ} \mathrm{C} \text {. } \\
\text { For an extended period it is recommended to freeze the } \\
\text { sample at }-80^{\circ} \mathrm{C} \text {, without centrifugation or filtration. } \\
\text { After thawing of the sample, possible precipitates can } \\
\text { be easily removed by dissolving the sample at } 37^{\circ} \mathrm{C} \text {. } \\
\text { Blurry urine samples should be centrifuged. }\end{array}$ \\
\hline & Degradation of total protein before analysis & $\begin{array}{l}\text { The proteins are susceptible to bacterial degradation } \\
\text { at room temperature. Analysis should be performed as } \\
\text { quickly as possible. Samples may be stored for up to } 1 \\
\text { week at }+4^{\circ} \mathrm{C} \text {, for longer storage frozen at }-20^{\circ} \mathrm{C} \text { or at } \\
-80^{\circ} \mathrm{C} \text {. Samples should be dissolved at } 37^{\circ} \mathrm{C} \text { to prevent } \\
\text { degradation of proteins and after homogenizing, } \\
\text { samples should be centrifuged prior to analysis }\end{array}$ \\
\hline
\end{tabular}

ACR - albumin-to-creatinine ratio. PCR - protein-to-creatinine ratio. AKI - acute kidney injury. CCMB - Croatian Chamber of Medical Biochemists.

(Reproduced and adapted with permission from KDIGO 2012 Clinical Practice Guideline for the Evaluation and Management of Chronic Kidney Disease. Kidney Int, Suppl 2013;3:1-150.)

puberty, the presence of obesity (high BMI) and may be modified by exercise, fever and posture (1). In children with CKD any expression of abnormal urinary protein excretion may utilize proteinuria in place of albuminuria. Children older than 24 months of age are expected to achieve normal (adult) protein values (1). 


\section{Recommendations}

1. Measure albumin preferably in a morning urine specimen.

2. Measure urine creatinine in the same urine sample.

3. Express the results as albumin-to-creatinine ratio (ACR) in recommended units $(\mathrm{mg} / \mathrm{mmol})$.

4. A positive finding of albuminuria in a random sample of urine needs to be confirmed in the next morning void urine.

5. If a more accurate estimate of albuminuria is required, it is recommended to measure albumin excretion rate (AER), with reference interval $<30 \mathrm{mg} / 24$ hours, independently of sex and age.

6. In children with CKD proteinuria should be preferred over albuminuria, especially in children $<2$ years of age.

7. Adult values for AER and ACR apply for children older than 24 months of age.

\section{PCR}

\subsection{Preanalytical phase}

Filtered serum proteins, proteins derived from the kidney and urinary tract make normal urine protein content (63). Their appearance is influenced by renal, pre- and postrenal conditions (64). Urine as a body fluid for clinical analysis is relatively stable, probably due to the fact that it is "stored" for hours in the bladder; hence, proteolytic degradation by endogenous proteases may be essentially complete by the time of voiding (65).

Total protein in urine may be increased after heavy exercise, dehydration, very high protein intake and emotional stress (66). Vaginal and urethral secretions can produce false positive, and diluted urine specimens can give false negative protein results (67). Because urine albumin is predominant protein in most proteinuric kidney diseases, all factors affecting urinary ACR also affect PCR (Table 7).

\section{Stability}

Proteins are susceptible to bacterial degradation at room temperature. Analysis should be performed as quickly as possible. Samples may be stored for up to 1 week at $+4{ }^{\circ} \mathrm{C}$, for longer storage frozen at $-20{ }^{\circ} \mathrm{C}$ or at $-80^{\circ} \mathrm{C}$. Samples should be dissolved at $37{ }^{\circ} \mathrm{C}$ to prevent degradation of proteins and after homogenizing, samples should be centrifuged prior to analysis (68).

\subsection{Analytical phase}

There is no recommended method for measuring of total protein in the urine. The majority of laboratories use turbidimetric or colorimetric assays. These methods do not have the same analytical specificity and sensitivity for all proteins. Most methods reacts more strongly with albumin than with globulins and other non-albumin proteins.

There is no reference method and no standardized reference material for urine protein recommended by JCTLM. Different methods and calibrators lead to significant between-laboratory variation. It is difficult to define a standardized reference material since a variable mixture of different proteins is measured (1).

Desirable and optimal specifications for imprecision, bias and total error according to biological variation database (14) are shown in Table 4.

\subsection{Postanalytical phase}

Results of total urine protein measurement should be reported as PCR using the units $\mathrm{mg} / \mathrm{mmol}$ (Table 8). 
TABLE 8. Protein-to-creatinine ratio's categories in adults

\begin{tabular}{ll}
\hline Category & PCR \\
\hline P1 & $<15.0 \mathrm{mg} / \mathrm{mmol}$ \\
Normal to mild proteinuria & \\
\hline P2 & $15.0-50.0 \mathrm{mg} / \mathrm{mmol}$ \\
Moderate proteinuria & \\
\hline P3 & $>50.0 \mathrm{mg} / \mathrm{mmol}$ \\
Severe proteinuria & \\
\hline
\end{tabular}

Measurement of PCR to total protein concentration, in initial assessment of proteinuria, is to overcome variation in urine concentration and dilution (63).

\subsection{Pediatric considerations}

Neonates and young infants/children are both expected and allowed to have higher urinary losses of both glomerular and tubular proteinuria due to lack of maturation in the proximal tubular reabsorption of proteins. In children the quantification of total protein, as compared to the albumin only fraction, may be preferred method (1).

The normal ranges for albuminuria and proteinuria in children are shown in Table 9.

TABLE 9. Pediatric normal ranges for albuminuria and total proteinuria

\begin{tabular}{lcccc}
\hline & Unit & $<\mathbf{6}$ months & $\mathbf{6 - 2 4}$ months & $>\mathbf{2 4}$ months \\
\hline PER & $\mathrm{mg} / \mathrm{m}^{2} / \mathrm{day}$ & $<240$ & $<150$ & $<150$ \\
\hline PCR & $\mathrm{mg} / \mathrm{mmol}$ & $/$ & $<50$ & $<20$ \\
\hline AER & $\mathrm{mg} / \mathrm{day}$ & not known & not known & $<30$ \\
\hline ACR & $\mathrm{mg} / \mathrm{mmol}$ & not known & not known & $<3$ \\
\hline
\end{tabular}

PER - Protein Excretion Rate. PCR - Protein-to-Creatinine Ratio. AER - Albumin Excretion Rate. ACR - Albumin-to-Creatinine Ratio.

\section{Recommendations}

1. Measure total protein preferably in a morning urine specimen.

2. Measure urine creatinine in the same urine sample.

3. Express the results as protein-to-creatinine ratio $(P C R)$ in recommended units $(\mathrm{mg} / \mathrm{mmol})$.

4. A positive finding of proteinuria in a random sample of urine should be confirmed in the next morning void urine.

5. In adults, for a measure of protein excretion rate (PER) apply reference interval $<150 \mathrm{mg} / 24$ hours, independently of sex and age.

6. In children, the quantification of total protein, as compared to the albumin only fraction, may be preferred method.

\section{Conclusion}

There are many issues that need to be resolved in the laboratory diagnostics of CKD in Croatia (8). Although there were many potential biomarkers suggested for the early diagnosis of $\operatorname{CKD}(69,70)$, considering the issues that were raised via the conducted survey (8), we need to approach the Croatian medical biochemistry laboratories at the very basic level. 
The principal clinical purpose of assessing a patient's renal function is to anticipate complications, enabling better screening and treatment decisions. Determining with great accuracy a certain physiologic parameter - actual GFR - is a less important goal (71) and inexpensive, easy and accurate measurement of serum creatinine could lead to reduction in the global burden of CKD (3). In connection to this, the very first goal is to introduce standardized assays for creatinine measurement and eGFR reporting in all medical biochemistry laboratories. The second goal is to harmonize the choice of the sample for ACR/PCR measurement and the reporting units, consequently.
The future perspectives include education in implementing the recommendations and conducting tho follow-up survey to observe the completeness and identifying "weak spots" of the recommendations implementation process. The obtained data will be a starting point for the second edition of the recommendations.

In conclusion, reporting the results of laboratory tests for the diagnosis of CKD should be aligned with the adopted general recommendations with the applicable reference intervals, diagnostic value, and the source is acknowledged criteria. An example of the recommended reporting in laboratory diagnostics of CKD is shown in Table 10.

TABLE 10. Recommended reporting of laboratory results

\begin{tabular}{|c|c|c|c|c|}
\hline Test/Analyte & Results & Unit & Diagnostic value & Reference \\
\hline $\begin{array}{l}\text { Estimation of glomerular filtration } \\
\text { rate (eGFR) }\end{array}$ & & $\mathrm{mL} / \mathrm{min} / 1,73 \mathrm{~m} 2$ & $\begin{array}{l}\text { GFR categories: } \\
\text { G1: } \geq 90 \\
\text { G2: } 60-89 \\
\text { G3a: } 45-59 \\
\text { G3b: } 30-44 \\
\text { G4: } 15-29 \\
\text { G5: }<15\end{array}$ & $\begin{array}{l}\text { KDIGO guidelines } \\
\text { (2012.) }\end{array}$ \\
\hline (U) Albumin-to-creatinine & & $\mathrm{mg} / \mathrm{mmol}$ & $\begin{array}{l}\text { Albuminuria categories: } \\
\text { A1: }<3.0 \\
\text { A2: } 3.0-30.0 \\
\text { A3: }>30.0\end{array}$ & $\begin{array}{l}\text { KDIGO guidelines } \\
\text { (2012.) }\end{array}$ \\
\hline (U) Protein-to-creatinine & & $\mathrm{mg} / \mathrm{mmol}$ & $\begin{array}{l}\text { Proteinuria categories } \\
\text { P1: }<15.0 \\
\text { P2: } 15.0-50.0 \\
\text { P3: }>50.0\end{array}$ & $\begin{array}{l}\text { KDIGO guidelines } \\
\text { (2012.) }\end{array}$ \\
\hline
\end{tabular}

\section{Acknowledgements}

The authors wish to thank KDIGO for granting permission for the use of KDIGO 2012 Clinical Practice Guideline for the Evaluation and Management of Chronic Kidney Disease internationally copyrighted material. We also thank Marijana Vučić Lovrenčić, Zlata Flegar-Meštrić and Mirjana SabljarMatovinović for granting permission for the use of internal document of Merkur University Hospital, as well as to Prof Graham Jones for giving grant to present an unpublished data shown in Appendix 3.

\section{Potential conflict of interest}

None declared. 


\section{References}

1. Kidney Disease: Improving Global Outcomes (KDIGO) CKD Work Group. KDIGO 2012 Clinical Practice Guideline for the Evaluation and Management of Chronic Kidney Disease. Kidney inter., Suppl. 2013;3:1-150.

2. Brück K, Jager KJ, Dounousi E, Kainz A, Nitsch D, Ärnlöv J, et al. Methodology used in studies reporting chronic kidney disease prevalence: a systematic review. Nephrol Dial Transplant 2015;30:iv6-iv16. https://doi.org/10.1093/ndt/ gfv131.

3. Harris DC. Global inequality in kidney care. Editorial. Med J Aust 2015;202:227-8. https://doi.org/10.5694/mja15.00035.

4. Croatian Society for Nephrology, Dialysis and Transplantation of Croatian Medical Association. Available at: http:// www.hdndt.org/index.html. Accessed April 12th 2016.

5. Lamb EJ, MacKenzie F, Stevens PE. How should proteinuria be detected and measured? Ann Clin Biochem 2009;46:20517. https://doi.org/10.1258/acb.2009.009007.

6. Johnson DW, Jones GRD, Methew TH, Ludlow MJ, Chadban SJ, Usherwood T, at al. Chronic kidney disease and measurement of albuminuria or proteinuria: a position statement. Med J Aust 2012;197:224-5. https://doi.org/10.5694/ mja11.11468.

7. Chronic kidney disease (2014) NICE guideline CG 182. Available at: https://pathways.nice.org.uk/pathways/chronickidney-disease. Accessed July 21st 2016.

8. Radišić Biljak V, Honović L, Matica J, Knežević B, Šimić Vojak S. Laboratory diagnostics of chronic kidney disease in Croatia: state of the art. Biochem Med (Zagreb) 2015;25:73-83. https://doi.org/10.11613/BM.2015.009.

9. Jones $G$. The New International Recommendations for Chronic Kidney Disease. Available at: https://www.aacc. org/publications/cln/articles/2014/october/kidney-disease. Accessed September 9th 2014.

10. Vučić Lovrenčić $M$, Flegar-Meštrić $Z$, Sabljar-Matovinović M. [Informacije za liječnike: Standardizirani kreatinin i procjena glomerularne filtracije (eGFR)]. Unpublished internal document of Merkur University Hospital; 2011. (in Croatian)

11. Nikolac N, Šupak-Smolčić V, Šimundić AM, Ćelap I. Croatian Society of Medical Biochemistry and Laboratory Medicine: national recommendations for venous blood sampling. Biochem Med (Zagreb) 2013;23:242-54. https://doi. org/10.11613/BM.2013.031.

12. Lenicek Krleza J, Dorotic A, Grzunov A, Maradin M. Capillary blood sampling: national recommendations on behalf of the Croatian Society of Medical Biochemistry and Laboratory Medicine. Biochem Med (Zagreb) 2015;25:335-58. https://doi.org/10.11613/BM.2015.034.

13. Zhang DJ, Elswick RK, Miller G, Bailey JL. Effect on serumclot time on clinical chemistry laboratory results. Clin Chem 1998:44;1325-33.

14. Desirable biological variation database specifications. Available at: https://www.westgard.com/biodatabase1.htm. Accessed February 13th 2015.
15. Sandberg S, Fraser CG, Horvath AR, Jansen $R$, Jones $G$, Oosterhuis $W$, et al. Defining analytical performance specifications: Consensus Statement from the 1st Strategic Conference of the European Federation of Clinical Chemistry and Laboratory Medicine. Clin Chem Lab Med 2015;53:833-5. https://doi.org/10.1515/cclm-2015-0067.

16. Flegar Meštrić Z. [Standardizacija mjerenja koncentracije kreatinina.] In: [Harmonizacija medicinsko-biokemijskih pretraga - 2011]. Flegar Meštrić Z, Honović L, eds. Zagreb: Medicinska naklada; 2011. (in Croatian)

17. Drion I, Cobbaert C, Groenier KH, Weykamp C, Bilo HJG, Wetzels JFM, et al. Clinical evaluation of analytical variations in serum creatinine measurements: why laboratories should abandon Jaffe techniques. BMC Nephrology 2012;13:133. https://doi.org/10.1186/1471-2369-13-133

18. Kuster N, Cristol J-P, Cavalier E, Bargnoux A-S, Halimi J-M, Froissart $M$, et al. Enzymatic creatinine assays allow estimation of glomerular filtration rate in stages 1 and 2 chronic kidney disease using CKD-EPI equation. Clin Chim Acta 2014;428:89-95. https://doi.org/10.1016/j.cca.2013.11.002.

19. Veiga Cheuiche A, Aguiar Soares A, Guimarães Camargo $E$, Schwerz Weinert L, Lins Camargo J, Pinho Silveiro S. Comparison between IDMS-traceable Jaffe and enzymatic creatinine assays for estimation of glomerular filtration rate by the CKD-EPI equation in healthy and diabetic subjects. Clin Biochem 2013;46:1423-9. https://doi.org/10.1016/j.clinbiochem.2013.05.067.

20. Jones GRD. Creatinine assays - global progress on implementing IDMS traceability. Clin Chem Lab Med 2015;53(Special Suppl):S1-S1450. https://doi.org/10.1515/cclm-20155027.

21. Laboratory measurement of creatinine. Available at: http:// bestpractice.bmj.com/best-practice/monograph/935.html. Accessed September 30th 2014.

22. Myers GL, Miller WG, Coresh J, Fleming J, Greenberg N, Greene $T$, et al. Recommendations for Improving Serum Creatinine Measurement: A Report from the Laboratory Working Group of the National Kidney Disease Education Program. Clin Chem 2006;52:5-18. https://doi.org/10.1373/ clinchem.2005.0525144.

23. Samra M, Abcar AC. False Estimates of Elevated Creatinine. Perm J 2012;16:51-2. https://doi.org/10.7812/TPP/11-121.

24. Cuhadar S. Preanalytical variables and factors that interfere with the biochemical parameters: a review. OA Biotechnology 2013;2:19.

25. Nikolac N. Lipemia: causes, interference mechanisms, detection and management. Biochem Med (Zagreb) 2014;24:5767. https://doi.org/10.11613/BM.2014.008.

26. Greenberg N, Roberts WL, Bachmann LM, Wright EC, Dalton $R N$, Zakowski JJ, et al. Specificity characteristics of 7 commercial creatinine measurement procedures by enzymatic and Jaffe method principles. Clin Chem 2012;58:391-401. https://doi.org/10.1373/clinchem.2011.172288.

27. Nikolac N, Celap I, Filipi P, Hemar M, Kocijancic M, Miler M, et al. Croatian laboratories have a good knowledge of the proper detection and management of hemolyzed, icteric and lipemic samples. Clin Chem Lab Med 2016;54:419-25. https:// doi.org/10.1515/cclm-2015-0650. 
28. Dimeski G. Interference Testing. Clin Biochem Rev 2008;29:S43-S48.

29. Culjak M, Nikolac N, Simundic AM. Short-term storage stability of serum angiotensin-converting enzyme (ACE) activity. Clin Chim Acta 2015;446:261-2. https://doi.org/10.1016/j. cca.2015.05.001.

30. Nikolac $N$, Simundic AM, Miksa M, Lima-Oliveira G, Salvagno $G L$, Caruso B, et al. Heterogeneity of manufacturers' declarations for lipemia interference - An urgent call for standardization. Clin Chim Acta 2013;426:33-40. https:// doi.org/10.1016/j.cca.2013.08.015.

31. Croatian Chamber of Medical Biochemists. [Revizija preporučenih metoda i referentnih intervala koncentracije kreatinina u serumu i urinu]. Available at: http://www.hkmb.hr/ obavijesti/arhiva2010/arhiva_2010.html. Accessed October 14th 2014. (in Croatian)

32. Croatian Chamber of Medical Biochemists. [Preporuka za postupanje u nedostatku referentnog intervala]. Available at: http://www.hkmb.hr/obavijesti/arhiva2010/2010_refinterval.html. Accessed October 14th 2014. (in Croatian)

33. Flegar-Meštrić Z, Perkov S, Šimonović B, Juretić D. Applicability of common reference intervals for serum creatinine concentrations to the Croatian population. Clin Chem Lab Med 2010;48:231-5. https://doi.org/10.1515/CCLM.2010.054.

34. Levey AS, Stevens LA, Schmid CH, Zhang Y, Castro III AF, Feldman $\mathrm{Hl}$, et al. New Equation to Estimate Glomerular Filtration Rate. Ann Intern Med 2009;150:604-12. https://doi. org/10.7326/0003-4819-150-9-200905050-00006.

35. The CKD-EPI Equation. Available at: http://nkdep.nih.gov/ lab-evaluation/gfr/estimating.shtml\#the-ckd-epi-equation. Accessed November 18th 2014.

36. Delange JR. How to estimate GFR in children. Nephrol Dial Transplant 2009;24:714-6. https://doi.org/10.1093/ndt/gfn306.

37. Cobbaert CM, Baadenhuijsen $H$, Weykamp CW. Prime time for enzymatic creatinine methods in pediatrics. Clin Chem 2009;55:549-58. https://doi.org/10.1373/ clinchem.2008.116863.

38. CALIPER Study - CALIPER Pediatric reference Intervals Available at: http://www.sickkids.ca/Caliperproject/intervals/index.html. Accessed Novemebr 16th 2016.

39. Colantonio DA, Kyriakopoulou L, Khun Chan M, Daly $C H$, Brinc $D$, Venner $A A$, et al. Closing the gaps in pediatric laboratory reference intervals: A CALIPER database of $40 \mathrm{bi}$ ochemical markers in a healthy and multiethnic population of children. Clin Chem 2012;58:854-68. https://doi. org/10.1373/clinchem.2011.177741.

40. Higgins $V$, Khun Chan $M$, Nieuwesteeg $M$, Hoffman BR, Bromberg IL, Gornall D, et al. Transference of CALIPER pediatric reference intervals to biochemical assays on the Roche cobas 6000 and the Roche Modular P. Clin Biochem 2016;49:139-49. https://doi.org/10.1016/j.clinbiochem.2015.08.018.

41. Estey MP, Cohen AH, Colantonio DA, Khun Chan M, Binesh Marvasti T, Randell E, et al. CLSI-based transference of the CALIPER database of pediatric reference intervals from $\mathrm{Ab}$ bott to Beckman, Ortho, Roche and Siemens Clinical Chemistry Assays: Direct validation using reference samples from the CALIPER cohort. Clin Biochem 2013;46:1197-219. https://doi.org/10.1016/j.clinbiochem.2013.04.001.
42. IFCC Pediatric Reference Range Intiatives. Available at: http://www.ifcc.org/task-force-paediatric-laboratory-medicine-web-pages/paediatric-reference-range-initiatives/. Accessed August 2nd 2016.

43. Inker LA, Levey AS. Pro: Estimating GFR using the chronic kidney disease epidemiology collaboration (CKD-EPI) 2009 creatinine equation: the time for change is now. Nephrol Dial Transplant 2013;28:1390-6. https://doi.org/10.1093/ ndt/gft003.

44. Earley A, Miskulin D, Lamb EJ, Levey AS, Uhlig K. Estimating Equations for Glomerular Filtration Rate in the Era of Creatinine Standardization. A Systematic Review. Ann Intern Med 2012;156:785-95. https://doi.org/10.7326/0003-4819-15611-201203200-00391.

45. Florkowski CM, Chew-Harris JSC. Methods of Estimating GFR - Different Equations Including CKD-EPI. Clin Biochem Rev 2011;32:75-9.

46. Levey AS, Eckfeldt JH. Using Glomerular Filtration Rate Estimating Equations: Clinical and Laboratory Considerations. Editorial. Clin Chem 2015;1226-9. https://doi.org/10.1373/ clinchem.2015.245282.

47. Iliadis F, Didangelos T, Ntemka A, Makedou A, Moralidis E, Gotzamani-Psarakou $A$, et al. Glomerular filtration rate estimation in patients with type 2 diabetes: creatinine- or cystatin C-based equations? Diabetologia 2011;54:2987-94. https://doi.org/10.1007/s00125-011-2307-1.

48. Vučić Lovrenčić $M$, Radišić Biljak $V$, Božičević $S$, Prašek $M$, Knotek M. Estimating glomerular filtration rate (GFR) in diabetes: The performance of MDRD and CKD-EPI equations in patients with various degrees of albuminuria. Clin Biochem 2012;45:1694-6. https://doi.org/10.1016/j.clinbiochem.2012.07.115.

49. Stevens LA, Schmid CH, Zhang YL, Coresh J, Manzi J, Landis $R$, et al. Development and validation of GFR-estimating equations using diabetes, transplant and weight. Nephrol Dial Transplant 2010;25:449-57. https://doi.org/10.1093/ ndt/gfp510.

50. Stevens LA, Levey AS. Measured GFR as a Confirmatory Test for Estimated GFR. J Am Soc Nephrol 2009;20:2305-13. https://doi.org/10.1681/ASN.2009020171.

51. O'Riordan P, Stevens PE, Lamb EJ. Estimated glomerular filtration rate. BMJ 2014;348:g264. https://doi.org/10.1136/ bmj.g264.

52. Chew-Harris J, Florkowski C, Elmslie J, Livesey J, Endre Z, George P. Lean mass and age are strong determinants of glomerular filtration rate in healthy men. Abstract. Clin Chem Lab Med 2015;53:S1090. https://doi.org/10.1097/01. pat.0000461558.08084.7f.

53. Tonelli $M$, Riella $M$. Chronic kidney disease and the aging population. Nephrol Dial Transplant 2014;29:221-24. https://doi.org/10.1093/ndt/gft519.

54. Schwartz GJ, Muñoz A, Schneider M, Mak RH, Kaskel F, Warady $B A$, et al. New equations to estimate GFR in children with CKD.J Am Soc Nephrol 2009;20:629-37. https://doi. org/10.1681/ASN.2008030287.

55. GFR Calculator for Children. Available at: http://nkdep.nih. gov/lab-evaluation/gfr-calculators/children-SI-units.asp. Accessed November 18th 2014. 
56. Miler M, Šimundić AM. Low level of adherence to instructions for 24-hour urine collection among hospital outpatients. Biochem Med (Zagreb) 2013;23:316-20. https://doi. org/10.11613/BM.2013.038.

57. Sacks DB, Arnold M, Bakris GL, Bruns DE, Horvath AR, Kirkman MS, et al. Guidelines and recommendations for laboratory analysis in the diagnosis and management of diabetes mellitus. Clin Chem 2011;57:e1-e47. https://doi. org/10.1373/clinchem.2010.161596.

58. Croatian Chamber of Medical Biochemists. [Standardi dobre stručne prakse. Upute za uzimanje uzorka mokraće za kvalitativnu analizu]. Available at: http://www.hkmb.hr/povjerenstva/strucna-pitanja.html. Accessed August 3rd 2016. (in Croatian)

59. Kuori T, Fogazzi G, Gant V, Hallander H, Hofmann W, Guder WG. European urinalysis guidelines. Scand J Clin Lab Invest 2000;60:1-96.

60. Miller WG, Bruns DE, Hortin GL, Sandberg S, Aakre KA, McQueen MJ, et al. Current issues in measurement and reporting urinary albumin excretion. Clin Chem 2009;55:2438. https://doi.org/10.1373/clinchem.2008.106567.

61. Graziani MS, Plebani M. The standardization of the urine albumin assays: no longer deferrable. Editorial. Clin Chem Lab Med 2015;53:1657-9. https://doi.org/10.3167/ arcs.2015.010101.

62. Martin H. Laboratory measurement of urine albumin and urine total protein in screening for proteinuria in chronic kidney disease. Clin Biochem Rev 2011;32:97-102.
63. Levey AS, Becker C, Inker LA. Glomerular Filtration Rate and Albuminuria for Detection and Staging of Acute and Chronic Kidney Disease in Adults. JAMA 2015;313:837-46. https://doi.org/10.1001/jama.2015.0602.

64. Thomas L, ed. Clinical Laboratory Diagnostics. Use and Assessment of Clinical Laboratory Results. Frankfurt/Main, Germany: TH-Books Verlagsgeselschaft, 1998.

65. Good DM, Zürbig P, Argilés A, Bauer HW, Behrens G, Coon $J$, et al. Naturally occurring human urinary peptides for use in diagnosis of chronic kidney disease. Mol Cell Proteomics 2010;9:2424-37. https://doi.org/10.1074/mcp. M110.001917.

66. Ringsrud KM, Linne JJ, eds. Urinanalysis and Body Fluids: A Colortext and Atlas. 1st ed. St. Louis, Missouri: Mosby, 1995.

67. Mundt L, Shanahan K, eds. Graff's Handbook of Routine Urinalysis. Philadelphia: Lippincott, Williams and Wilkins; 1982.

68. Le Bricon T. [Biological analysis of proteinuria in the la boratory: quantitative features]. Ann Biol Clin (Paris) 2001;59:701-15. (in French)

69. Pedroza-Díaz J, Röthlisberger S. Advances in urinary protein biomarkers for urogenital and non-urogenital pathologies. Biochem Med (Zagreb) 2015;25:22-35. https://doi. org/10.11613/BM.2015.003.

70. Lopez-Giacoman S, Madero M. Biomarkers in chronic kidney disease, from kidney function to kidney damage. World J Nephrol 2015;4:57-73. https://doi.org/10.5527/wjn. v4.i1.57.

71. Hsu C, Bansal N. Measured GFR as "Gold Standard" - All that Glitters Is not Gold? Editorial. Clin J Am Soc Nephrol 2011;6:1813-4. https://doi.org/10.2215/CJN.06040611. 
APPENDIX 1. Step-by-step flow chart for implementation of the recommendations for laboratory diagnostics of chronic kidney disease (CKD)

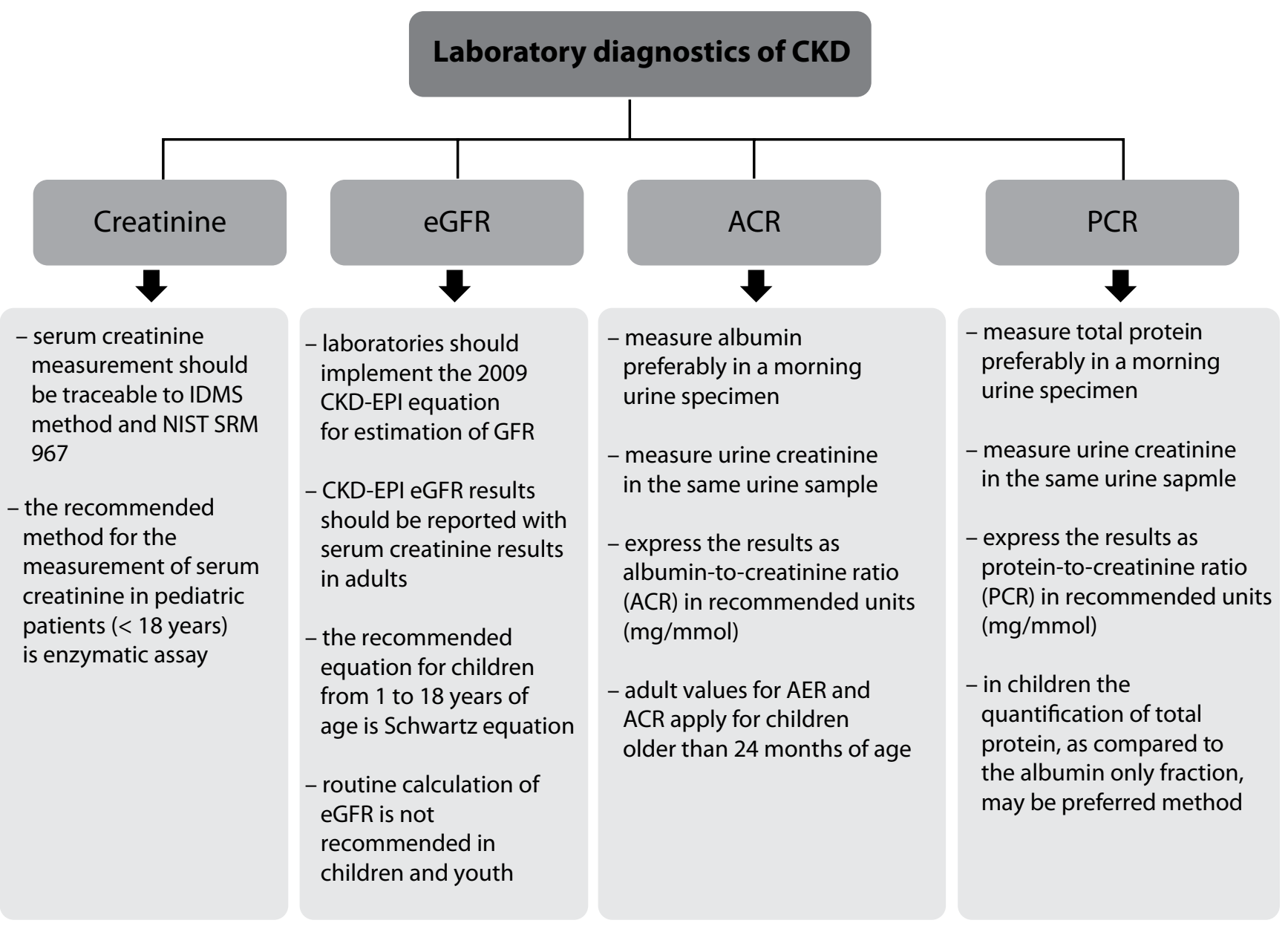

APPENDIX 2. Informations for physicians

\section{INFORMATIONS FOR PHYSICIANS:}

Standardized creatinine and evaluation of estimated glomerular filtration rate

\begin{tabular}{ll}
\hline Question & Answer \\
\hline $\begin{array}{l}\text { What is a standardized } \\
\text { creatinine? }\end{array}$ & $\begin{array}{l}\text { Standardized creatinine is a result of the determination of serum creatinine by method } \\
\text { (enzymatic or compensated Jaffé) calibrated with standard NIST SRM 967th }\end{array}$ \\
\hline & $\begin{array}{l}\text { Generally: } \\
\text { By standardization of creatinine we compensated systematic analytical error in current } \\
\text { non-specific methods, which allowed standardization and enabled global comparability of }\end{array}$ \\
$\begin{array}{l}\text { Why we introduce a standardized } \\
\text { reaults of serum creatinine and application of uniform reference intervals. }\end{array}$ \\
$\begin{array}{l}\text { Specifically: } \\
\text { Standardized creatinine is a prerequisite for the implementation of international guidelines } \\
\text { for the early diagnosis and monitoring progression of chronic kidney disease in risk } \\
\text { populations (hypertension, diabetes, etc.). }\end{array}$ \\
\hline
\end{tabular}




\section{What is the relation of standardized creatinine results and creatinine?}

Used methods showed a positive bias due to analytical interferention of exogenous and endogenous substances (pseudochromogene, most of the protein molecule, glucose, ketoacids), which provides a significant contribution to the intra- and inter-laboratory variability of results. To compensate part of non-specific interfering substances, the results of standardized creatinine are generally lower than that of creatinine. Important! There is no conversion formula or factor linking standardized creatinine and creatinine.

What are the reference
intervals for standardized
serum creatinine for adults and
how they are different from
the reference intervals for
creatinine?

What does this change in the
longitudinal monitoring of renal
function of the patient?

\section{What is eGFR?}

Why we introduce eGFR?

What is the recommended equation for calculating eGFR?

\begin{tabular}{cccc} 
Gender (age, years) & Standardized creatinine & Creatinine & Units \\
\hline $\begin{array}{c}\text { Male } \\
(18-74)\end{array}$ & $64-104$ & $79-125$ & $\mu \mathrm{mol} / \mathrm{L}$ \\
\hline $\begin{array}{c}\text { Female } \\
(18-74)\end{array}$ & $49-90$ & $63-107$ & $\mu \mathrm{mol} / \mathrm{L}$
\end{tabular}

Absolute results of standardized creatinine and creatinine are not comparable; relative comparability is achieved by applying appropriate reference intervals!

eGFR is estimated glomerular filtration rate; calculated from serum creatinine and demographic characteristics of the patient (age, gender, race).

For eGFR is not necessary to collect 24-hour urine!

eGFR is a prerequisite for the implementation of international guidelines for the early diagnosis and monitoring progression of chronic kidney disease in risk populations (hypertension, diabetes, etc.)

CKD-EPI equation with four variables (age, sex, race, concentration standardized serum creatinine) for adulthood.

Schwartz equation with two variables (height of the child, the concentration of a standardized serum creatinine) for children.

\begin{tabular}{|c|c|c|}
\hline What are the units for eGFR? & $\mathrm{mL} / \mathrm{min} / 1.73 \mathrm{~m}^{2}$ & \\
\hline \multirow{8}{*}{$\begin{array}{l}\text { What are the reference intervals } \\
\text { for eGFR? }\end{array}$} & \multicolumn{2}{|c|}{ There are none! We use eGFR for classification of renal impairment: } \\
\hline & Stage of chronic kidney disease & Glomerular filtration $(\mathrm{mL} / \mathrm{min} / 1.73 \mathrm{m2})$ \\
\hline & 1 & $>=90$ \\
\hline & 2 & $60-89$ \\
\hline & $3 a$ & $45-59$ \\
\hline & $3 b$ & $30-44$ \\
\hline & 4 & $15-29$ \\
\hline & 5 & $<15$ \\
\hline
\end{tabular}

What are limitations of equations for estimating GFR?

When and whom can estimate
GFR?

When and to whom can not be estimate GFR?

Schwartz equation requires the measurement of serum creatinine by enzymatic method.

All persons in whom there is no acute condition, and determined the expression level of a standardized serum creatinine.

In states that follow acute changes of renal function, conditions after limb amputation and all states followed extreme changes in muscle mass.

Very obese and malnourished people, pregnant women.

Creatinine clearance is used for the measurement of the glomerular filtration rate. However, there are numerous sources of variability that compromise the accuracy of the results (physiological - tubular secretion of creatinine, pharmacologically - diuretics, analytical - interfering, practical - errors in collecting 24-hour urine).

Therefore, to estimate glomerular filtration rate is recommended eGFR calculation from serum creatinine

\section{What is the role of creatinine clearance in the assessment of renal function?}

(Adapted from an internal document of the Merkur University Hospital, reproduced with the written permission from the authors: Vučić Lovrenčić M, Flegar-Meštrić Z, Sabljar-Matovinović M.) 
APPENDIX 3. Currently available creatinine reagents with the information on assay traceability - unpublished data from Radišić Biljak $V$ and Jones $G$.

\begin{tabular}{|c|c|c|c|c|}
\hline Company & Test Kit Name & Assay Type & Supplied Calibration Information & $\begin{array}{l}\text { "IDMS } \\
\text { traceable" }\end{array}$ \\
\hline Abbott & - & Jaffe & Calibrator values traceable to SRM 967 using IDMS & Yes \\
\hline Abbott & - & Enzymatic & Calibrator values traceable to SRM 967 using IDMS & Yes \\
\hline Abbott & Creatinine & Jaffe & $\begin{array}{l}\text { For information on calibrator standardization, refer } \\
\text { to Multiconstituent Calibrator package insert. }\end{array}$ & Not declared \\
\hline Abbott & $\begin{array}{l}\text { Creatinine } \\
\text { (Enzymatic) }\end{array}$ & Enzymatic & $\begin{array}{l}\text { For information on calibrator standardization, refer } \\
\text { to the MULTIGENT Clin Chem Cal package insert }\end{array}$ & Not declared \\
\hline Abbott & i-STAT creatinine & $\begin{array}{l}\text { Enzymatic (whole } \\
\text { blood) }\end{array}$ & $\begin{array}{l}\text { Creatinine values assigned to i-STAT controls and } \\
\text { calibration verification materials are traceable to the } \\
\text { US National Institute of Standards and Technology } \\
\text { (NIST) standard reference material (SRM967). Further } \\
\text { information available from Abbott. }\end{array}$ & Yes \\
\hline Accurex & $\begin{array}{l}\text { AutoZyme } \\
\text { Creatinine }\end{array}$ & Jaffe & Not specified & Not specified \\
\hline $\begin{array}{l}\text { AMS } \\
\text { Diagnostics }\end{array}$ & Creatinine Reagent & Jaffe & $\begin{array}{l}\text { Use an aqueous creatinine standard or an } \\
\text { appropriate serum calibrator }\end{array}$ & Not specified \\
\hline Arkray & $\begin{array}{l}\text { Spotchem } \\
\text { creatinine }\end{array}$ & Reagent strip & Spot chem calibrator or calibration by reagent card & Not specified \\
\hline $\begin{array}{l}\text { Audit } \\
\text { Diagnostics }\end{array}$ & Creatinine Jaffe & Jaffe & Standard $(177 \mu \mathrm{mol} / \mathrm{L})$ & Not specified \\
\hline $\begin{array}{l}\text { Beckman } \\
\text { Coulter }\end{array}$ & CR-S & Jaffe & IDMS (in calibrator IFU, Aqua Cal) & Yes \\
\hline $\begin{array}{l}\text { Beckman } \\
\text { Coulter }\end{array}$ & CR-E & Enzymatic & IDMS (in calibrator IFU, Aqua Cal) & Yes \\
\hline $\begin{array}{l}\text { Beckman Coulter } \\
\text { (Olympus) }\end{array}$ & Creatinine & Jaffe & $\begin{array}{l}\text { Cal values Traceable NIST or Thermo Fisher Scientific } \\
2 \text { / NERL or reference methods. }\end{array}$ & Yes \\
\hline $\begin{array}{l}\text { Beckman } \\
\text { Coulter }\end{array}$ & Creatinine & Jaffe & $\begin{array}{l}\text { Cal values traceable to NIST SRM } 967 \text { for method A. } \\
\text { Cal values traceable to NIST SRM 909b for method B. }\end{array}$ & Yes \\
\hline $\begin{array}{l}\text { Beckman } \\
\text { Coulter }\end{array}$ & $\begin{array}{l}\text { Creatinine } \\
\text { (Enzymatic) }\end{array}$ & Enzymatic & Cal values traceable to NIST SRM 967 & Yes \\
\hline $\begin{array}{l}\text { BioMed } \\
\text { Diagnostics }\end{array}$ & Creatinine & $\begin{array}{l}\text { Jaffe, Colorimetric, } \\
\text { endpoint }\end{array}$ & Creatinine standard supplied $(2.0 \mathrm{mg} / \mathrm{dL})$ & Not specified \\
\hline $\begin{array}{l}\text { BioMed } \\
\text { Diagnostics }\end{array}$ & Creatinine & Jaffe, fixed rate & Creatinine standard supplied $(2.0 \mathrm{mg} / \mathrm{dL})$ & Not specified \\
\hline Biotecnica & Creatinine & Jaffe & $\begin{array}{l}\text { The concentration of the supplied standard was } \\
\text { determined using the NIST 914a international } \\
\text { standard. }\end{array}$ & Yes \\
\hline BQ Kits & $\begin{array}{l}\text { Creatinine Liquid } \\
\text { Reagents Assay }\end{array}$ & Enzymatic & Calibrator included. Traceable to NIST SRM 914a. & Yes \\
\hline Chemhouse & $\begin{array}{l}\text { Creatinine (kinetic, } \\
\text { Jaffes method) }\end{array}$ & Jaffe & Creatinine standard $2 \mathrm{mg} / \mathrm{dL}$ & Not specified \\
\hline Diasys & Creatinine FS & Jaffe & $\begin{array}{l}\text { Standard }(2 \mathrm{mg} / \mathrm{dL}) \text {. Subtract } 27 \mu \mathrm{mol} / \mathrm{L} \text { for } \\
\text { compensated method }\end{array}$ & Yes \\
\hline Diasys & Creatinine PAP FS & Enzymatic & Standard (2 mg/dL). & Yes \\
\hline Diazyme & $\begin{array}{l}\text { Enzymatic } \\
\text { creatinine }\end{array}$ & Enzymatic & $\begin{array}{l}\text { calibrator provided is traceable to NIST's SRM } 967 \\
\text { (GC-IDMS and LC-IDMS) }\end{array}$ & Yes \\
\hline
\end{tabular}




\begin{tabular}{|c|c|c|c|c|}
\hline $\begin{array}{l}\text { Fortress } \\
\text { diagnostics }\end{array}$ & Creatinine & Jaffe & $\begin{array}{l}\text { For automated systems recommend a serum based } \\
\text { calibrator to eliminate any matrix bias which may } \\
\text { be observed with the aqueous standard. Fortress } \\
\text { calibrator Cat BXCO321K/L/M }\end{array}$ & Not specified \\
\hline $\begin{array}{l}\text { Fortress } \\
\text { diagnostics }\end{array}$ & Creatinine & $\begin{array}{l}\text { Jaffe - } \\
\text { deproteinised }\end{array}$ & Supplied standard $177 \mu \mathrm{mol} / \mathrm{L}$. & Not specified \\
\hline $\begin{array}{l}\text { Fortress } \\
\text { diagnostics }\end{array}$ & Creatinine & $\begin{array}{l}\text { Jaffe - } \\
\text { deproteinised }\end{array}$ & $\begin{array}{l}\text { For automated use we recommend a serum based } \\
\text { calibrator to eliminate any matrix bias which may } \\
\text { be observed with the aqueous standard. Fortress } \\
\text { Calibrator cat. No BXC0321K/L/M }\end{array}$ & Yes \\
\hline Fujifilm & $\begin{array}{l}\text { Dri-chem slide } \\
\text { CRE-PIII }\end{array}$ & $\begin{array}{l}\text { Enzymatic (for Fuji } \\
\text { analyser) }\end{array}$ & $\begin{array}{l}\text { Traceability of Calibrators: NIST (SRM 914) Note } \\
\text { reference material is applied to the reference } \\
\text { method of Fujifilm corporation and is not directly } \\
\text { applicable to the Fuji dri-chem slide }\end{array}$ & Yes \\
\hline Genzyme & Creatinine-S Assay & Jaffe & Calibration material not supplied & Not specified \\
\hline I.S.E. S.r.I. & Creatinine & Jaffe & Multicalibrator I.S.E code R030000006 & Not specified \\
\hline IBL America & $\begin{array}{l}\text { Creatinine Liquid } \\
\text { Reagents Assay }\end{array}$ & Enzymatic & Calibrator included. Traceable to NIST SRM 914a. & Yes \\
\hline ID Labs & $\begin{array}{l}\text { IDTox Creatinine } \\
\text { Enzymatic }\end{array}$ & Jaffe, microplate & Standard "20 g/dL" & Not specified \\
\hline $\begin{array}{l}\text { Ortho Clinical } \\
\text { Diagnostics }\end{array}$ & - & Enzymatic & Not specified & Yes \\
\hline $\begin{array}{l}\text { Nova } \\
\text { Biomedical }\end{array}$ & $\begin{array}{l}\text { Creatinine whole } \\
\text { blood }\end{array}$ & - & Not specified & Adjustable \\
\hline Piccolo & Kidney Check & Enzymatic & Not specified & Not specified \\
\hline Pointe Scientific & $\begin{array}{l}\text { Creatinine reagent } \\
\text { set }\end{array}$ & Jaffe & $\begin{array}{l}\text { Use an NIST traceable creatinine standard }(2.5 \mathrm{mg} / \\
\mathrm{dL}) \text { or serum calibrator. }\end{array}$ & Not specified \\
\hline Pointe Scientific & $\begin{array}{l}\text { Creatinine reagent } \\
\text { set }\end{array}$ & Enzymatic & $\begin{array}{l}\text { Use an NIST traceable creatinine standard }(2.5 \mathrm{mg} / \\
\mathrm{dL}) \text { or serum calibrator. }\end{array}$ & Not specified \\
\hline Robonik & Prietest Creatinine & Jaffe & Standard provided ( $2 \mathrm{mg} / \mathrm{dL})$ & Not specified \\
\hline Roche & $\begin{array}{l}\text { Creatinine Jaffe } \\
\text { method }\end{array}$ & Jaffe & $\begin{array}{l}\text { This method has been standardised against IDMS } \\
\text { (Isotope Dilution Mass Spectrometry). For the } \\
\text { USA the method has been standardised against a } \\
\text { primary reference mterial (SRM 914). }\end{array}$ & Yes \\
\hline Roche & $\begin{array}{l}\text { Creatinine Jaffe } \\
\text { Gen.2 }\end{array}$ & Jaffe & $\begin{array}{l}\text { This method has been standardised against IDMS } \\
\text { (Isotope Dilution Mass Spectrometry). For the USA } \\
\text { the method has been standardised against a primary } \\
\text { reference material (SRM } 914 \text { and SRM } 967 \text { (IDMS)). }\end{array}$ & Yes \\
\hline Roche & Crea plus & Enzymatic & $\begin{array}{l}\text { This method has been standardised against IDMS } \\
\text { (Isotope Dilution Mass Spectrometry). }\end{array}$ & Yes \\
\hline Roche & Crea plus ver.2 & Enzymatic & $\begin{array}{l}\text { This method has been standardised against IDMS } \\
\text { (Isotope Dilution Mass Spectrometry). }\end{array}$ & Yes \\
\hline Sekisui & $\begin{array}{l}\text { Enzymatic } \\
\text { Creatinine } 265 \\
\text { series }\end{array}$ & Enzymatic & Not specified & Yes \\
\hline Sekisui & $\begin{array}{l}\text { Enzymatic } \\
\text { Creatinine } 265 \\
\text { series }\end{array}$ & Jaffe & Not specified & Yes \\
\hline Sentinel & Creatinine & Jaffe & IFU not seen & Not specified \\
\hline Sentinel & $\begin{array}{l}\text { Multigent } \\
\text { Creatinine }\end{array}$ & Enzymatic & correlation with Roche enzymatic (on DXc) & Yes \\
\hline
\end{tabular}




\begin{tabular}{|c|c|c|c|c|}
\hline Siemens -Advia & - & Jaffe & IFU not seen - Claim at NKDEP & Yes \\
\hline Siemens - Advia & - & Enzymatic & IFU not seen - Claim at NKDEP & Yes \\
\hline $\begin{array}{l}\text { Siemens - } \\
\text { Dimension }\end{array}$ & - & Jaffe & Not specified & No \\
\hline $\begin{array}{l}\text { Spectrum } \\
\text { (Egyptian } \\
\text { Company for } \\
\text { Biotechnology) }\end{array}$ & $\begin{array}{l}\text { Creatinine - Jaffe } \\
\text { (single reagent) }\end{array}$ & Jaffe & Standard $2 \mathrm{mg} / \mathrm{dL}$ & Not specified \\
\hline Spinreact & Creatinine & Jaffe & $\begin{array}{l}\text { Calibration with aqueous calibrator may cause a } \\
\text { systematic error in automated procedures. In these } \\
\text { cases it is recommended to use a serum calibrator. }\end{array}$ & Not specified \\
\hline Spinreact & Creatinine & Enzymatic & $\begin{array}{l}\text { Calibration with aqueous calibrator may cause } \\
\text { matrix related bias, it is recommended to use a } \\
\text { serum based calibrator. }\end{array}$ & Not specified \\
\hline Stanbio & $\begin{array}{l}\text { Creatinine Liquicolor } \\
\text { test (kinetic) }\end{array}$ & Jaffe & Standard included & Not specified \\
\hline Thermo & $\begin{array}{l}\text { Infinity Creatinine } \\
\text { Liquid stable } \\
\text { reagent }\end{array}$ & Jaffe & $\begin{array}{l}\text { "Calibrator or suitable aqueous creatinine standard". } \\
\text { "An aqueous standard or serum based calibrator } \\
\text { with and assigned value traceable to a primary } \\
\text { standard (eg. NIST or IRMM) is recommended" }\end{array}$ & Not specified \\
\hline Thermo & $\begin{array}{l}\text { Creatinine reagent } \\
\text { - Enzymatic }\end{array}$ & Enzymatic & $\begin{array}{l}\text { An aqueous standard or serum based calibrator with } \\
\text { an assigned value traceable to a primary standard } \\
\text { (eg. NIST or IRMM) is recommended }\end{array}$ & Not specified \\
\hline VITROSCIENT & $\begin{array}{l}\text { Creatinine (fixed } \\
\text { rate) }\end{array}$ & Jaffe & Standard not defined & Not specified \\
\hline VITROSCIENT & $\begin{array}{l}\text { Creatinine (fixed } \\
\text { rate) }\end{array}$ & $\begin{array}{l}\text { Jaffe, } \\
\text { deproteinised }\end{array}$ & Standard not defined & Not specified \\
\hline WAKO & Creatinine M L-type & Enzymatic & Wako system calibrator (available separately) & Not specified \\
\hline Wiener & Creatinina directa & Jaffe & Standard $20 \mathrm{mg} / \mathrm{L}$ creatinine solution & Not specified \\
\hline Wiener & Creatinina directa & Enzymatic & $\begin{array}{l}\text { Wiener Lab Calibrator ( } 3 \text { values for creatinine } \\
\text { depending on Wiener method) }\end{array}$ & Not specified \\
\hline $\begin{array}{l}\text { DiaSystem } \\
\text { Scandinavia AB }\end{array}$ & Creatinine Jaffe & Jaffe & $\begin{array}{l}\text { Calibrators traceable to NIST 9167, subtract } 27 \\
\mu \mathrm{mol} / \mathrm{L}\end{array}$ & Yes \\
\hline Medichem & & Enzymatic & Not specified & Not specified \\
\hline Randox & & Enzymatic & Not specified & Not specified \\
\hline Diachem & $\begin{array}{l}\text { CREATININE } \\
\text { ENZYMATIC }\end{array}$ & Enzymatic & $\begin{array}{l}\text { Calibration: S2: Creatinine standard found in the kit } \\
\text { or Roche C.F.A.S. (Calibrator for automated system) } \\
\text { or Roche cfas or Randox cal Li or level II }\end{array}$ & Not specified \\
\hline Pariksha Biotek & CREATININE - 2R KIT & Jaffe & Not specified & Not specified \\
\hline $\begin{array}{l}\text { Coral Clinical } \\
\text { Systems }\end{array}$ & $\begin{array}{l}\text { Creatinine Kit } \\
\text { (Mod Jaffe's kinetic } \\
\text { method) }\end{array}$ & Jaffe & $\begin{array}{l}\text { Supplied standard } 177 \mu \mathrm{mol} / \mathrm{L} \text {. "standard is traceable } \\
\text { to standard reference material (SRM) 909b." }\end{array}$ & Not specified \\
\hline Ensure Biotech & Creatinine EPK & Jaffe & Supplied standard $177 \mu \mathrm{mol} / \mathrm{L}$. & Not specified \\
\hline $\begin{array}{l}\text { Kamineni Life } \\
\text { Sciences }\end{array}$ & $\begin{array}{l}\text { Lifechem } \\
\text { Creatinine-LR }\end{array}$ & Jaffe & Supplied standard $177 \mu \mathrm{mol} / \mathrm{L}$. & Not specified \\
\hline KEE GAD Biogen & $\begin{array}{l}\text { Creatinine (Jaffe's } \\
\text { method) }\end{array}$ & Jaffe & Supplied standard $177 \mu \mathrm{mol} / \mathrm{L}$. & Not specified \\
\hline Recombigen & $\begin{array}{l}\text { Creatinine (Alkaline } \\
\text { Picrate method) }\end{array}$ & $\begin{array}{l}\text { Jaffe with } \\
\text { deproteinisation }\end{array}$ & Supplied standard $177 \mu \mathrm{mol} / \mathrm{L}$. & Not specified \\
\hline
\end{tabular}




\begin{tabular}{|c|c|c|c|c|}
\hline $\begin{array}{l}\text { AGGAPE } \\
\text { Diagnostics }\end{array}$ & $\begin{array}{l}\text { Enzymatic } \\
\text { Creatinine }\end{array}$ & Enzymatic & Supplied standard $177 \mu \mathrm{mol} / \mathrm{L}$. & Not specified \\
\hline $\begin{array}{l}\text { Linear } \\
\text { Chemicals SL }\end{array}$ & $\begin{array}{l}\text { Cromatest } \\
\text { Creatinine }\end{array}$ & Jaffe & $\begin{array}{l}\text { Supplied standard } 177 \text { umol/L. "Organic matrix } \\
\text { based primary standard. Concentration value is } \\
\text { traceable to Standard Reference Material 914a." }\end{array}$ & \\
\hline $\begin{array}{l}\text { Polymer } \\
\text { Technology }\end{array}$ & $\begin{array}{l}\text { PTS PANELS } \\
\text { Creatinine Test } \\
\text { Strips }\end{array}$ & $\begin{array}{l}\text { Enzymatic test strips } \\
\text { for use in CadioChek } \\
\text { PA analyser }\end{array}$ & $\begin{array}{l}\text { predicate device comparison: } A=0.93 \times B+0.49 \mathrm{mg} / \\
\mathrm{dL}\end{array}$ & Not specified \\
\hline bioMerieux SA & $\begin{array}{l}\text { Créatinine } \\
\text { cinétique (CREA) }\end{array}$ & Jaffe & $\begin{array}{l}\text { - Use Calimat (Ref. } 62 \text { 321): multiparametric calibrator } \\
\text { linked with SRM } 909 \\
\text { or } \\
\text { - Use Reagent } 1 \text { (Ref. } 61 \text { 162) linked with SRM } 914 \\
\text { Titer of Reagent 1:132.6 } \mathrm{\mu mol} / \mathrm{L} \\
\text { Aqueous solution prepared using 99\% pure creatinine }\end{array}$ & Not specified \\
\hline $\begin{array}{l}\text { Dijagnostika } \\
\text { d.o.o. }\end{array}$ & Kreatinin kinetički & Jaffe & $\begin{array}{l}\text { An aqueous standard or serum based calibrator with } \\
\text { and assigned value traceable to a primary standard } \\
\text { (eg NIST or IRMM) is recommended }\end{array}$ & Not specified \\
\hline $\begin{array}{l}\text { Dijagnostika } \\
\text { d.o.o. }\end{array}$ & $\begin{array}{l}\text { Kreatinin DST } \\
\text { (liquid) }\end{array}$ & Jaffe & $\begin{array}{l}\text { An aqueous standard or serum based calibrator with } \\
\text { and assigned value traceable to a primary standard } \\
\text { (eg NIST or IRMM) is recommended }\end{array}$ & Not specified \\
\hline Horiba ABX SAS & $\begin{array}{l}\text { ABX Pentra } \\
\text { Creatinine } 120 \mathrm{CP}\end{array}$ & Jaffe & ABX Pentra Multical required & Not specified \\
\hline Horiba ABX SAS & $\begin{array}{l}\text { ABX Pentra } \\
\text { Enzymatic } \\
\text { Creatinine CP }\end{array}$ & Enzymatic & ABX Pentra Multical required & Not specified \\
\hline Human & $\begin{array}{l}\text { auto-CREATININE } \\
\text { liquicolor }\end{array}$ & Jaffe & $\begin{array}{l}\text { auto-CREATININE is calibrated with AUTOCAL, which is } \\
\text { traceable to the reference material SRM 909b level } 2 \text {. }\end{array}$ & Not specified \\
\hline Human & $\begin{array}{l}\text { CREATININE } \\
\text { (ENZYM) liquicolor }\end{array}$ & Enzymatic & The method is traceable to the SRM 909c. & Not specified \\
\hline Human & $\begin{array}{l}\text { CREATININE } \\
\text { liquicolor }\end{array}$ & Jaffe & The method is traceable to the SRM 909b & Not specified \\
\hline
\end{tabular}

